\title{
KLASIKINIO MASAŽO IR IŠEMINĖS KOMPRESIJOS POVEIKIS KAKLO JUDESIŲ AMPLITUDEI IR SKAUSMUI
}

\author{
Pavelas Zachovajevas, Eglė Kačinskaitė, Brigita Zachovajevienė, Viktorija Kaktienė \\ Kauno kolegijos Medicinos fakultetas
}

Raktažodžiai: kaklinès dalies skausmas, klasikinis masažas, išeminè kompresija, galvos ir kaklo judesių amplitudè.

\section{Santrauka}

Kaklo skausmas yra vienas iš dažniausiai pasitaikančių skausmų. Kaklo skausmo paplitimas populiacijoje yra tarp 10 ir 15 proc., labiau paplitęs tarp moteru nei vyrų [6]. Miofascijinis skausmo sindromas yra dažnas, skausmingas griaučių - raumenų sistemos miofascijinių trigerinių taškų sukeltas sutrikimas [13]. Metodika. Tyrime dalyvavo 20 sveikatos sutrikimu neịvardijusių asmenų, kuriems viršutinèje kaklinèje stuburo dalyje nustatytas bent vienas latentinis miofascijinis trigerinis taškas. Tiriamieji buvo suskirstyti ¡ dvi grupes. I grupès $(n=10)$ tiriamiesiems buvo taikoma išeminès kompresijos procedūra, II grupès $(\mathrm{n}=$ 10) tiriamiesiems buvo taikomas klasikinis masažas toje puseje, kurioje nustatytas latentinis miofascijinis trigerinis taškas. Prieš tyrimą ir iškart po tyrimo buvo vertinama kaklo judesių amplitudè naudojant goniometrą, taip pat buvo naudojama vizualinè ir skaitmeninè analoginè skausmo skalè skausmo intensyvumui nustatyti.

Rezultatai. Tyrimo pradžioje įvertintas kiekvieno tiriamojo LMTT sukelto skausmo intensyvumas. I grupés asmenų skausmo intensyvumas buvo 7,3 $\pm 0,48$ balai, II grupès asmenų $-7,2 \pm 0,63$ balai. Po taikytos išeminès kompresijos asmenų skausmo intensyvumas siekè 2,3 $\pm 1,15$ balo, o asmenims, kuriems buvo taikomas klasikinis masažas, skausmas sumažèjo iki 4,8 $\pm 1,22$ balų. Visų tiriamujų skausmo intensyvumas reikšmingai sumažejo $(\mathrm{p}<0,05)$. Vertinant skausmo pokytị prieš ir po gydymo, asmenų, kuriems buvo taikoma išemine kompresija, skausmo pokytis buvo reikšmingai didesnis $(\mathrm{p}<0,05)$, nei II grupès asmenu, kuriems buvo taikomas klasikinis masažas.

Išvados. 1. Išeminè kompresija sumažina skausmo intensyvumą, sukeliamą lètinių miofascijinių trigerinių taškų, tačiau nedaro įtakos galvos ir kaklo judesių amplitudès kaitai. 2. Klasikinis masažas sumažina skausmo intensyvumą, sukeliamą lètinių miofascijinių trigerinių taškų, tačiau nedaro ịtakos galvos ir kaklo judesių amplitudès kaitai. 3. Išeminè kompresija veiksmingiau mažina lètinių miofascijinių trigerinių taškų sukeltą skausmą nei klasikinis masažas.

\section{Ivadas}

Skausmas - individualus ir subjektyvus patyrimas, kurị sunku apibrěžti ir kuris yra bendras visiems žmonèms. Tarptautinè skausmo studijų asociacija skausmą apibrèžia kaip nemalonų sensorinị ir emocinị patyrimą, susijusị su esamu ar potencialiu audinių pažeidimu, arba paciento apibūdinamu tokio pažeidimo terminu [8]. Lètinis skausmas turi didelę įtaką žmogaus gyvenimo kokybei. Remiantis Lietuvos statistikos departamento duomenimis, fizini skausmą jautè kas antras (53 proc.) 15 metų ir vyresnis gyventojas [14]. Skausmą dažniau jautė moterys (60 proc.) nei vyrai (45 proc.). Skausmą jaute 80 proc. (84 proc. moterų ir 72 proc. vyrų) 65 metų ir vyresnių gyventojų ir 26 proc. (33 proc. moterų ir 20 proc. vyrų) - 15-34 metų amžiaus.

Kaklo skausmas yra vienas dažniausiai pasitaikančių skausmų. Kaklo skausmo paplitimas populiacijoje yra tarp 10 ir 15 proc., labiau paplitęs tarp moterų nei vyrų [6]. Nustatyta, kad 44 milijonai amerikiečių jaučia miofascijinị skausmą. Atliktų tyrimų metu nustatyta, kad 30 proc. asmenų su nusiskundimais dèl skausmo turèjo aktyvius trigerinius taškus. Klinika, kurios pagrindiniai susirgimai galvos ir kaklo skausmai, pranešè, jog 55 proc. atvejų buvo dèl miofascijinio trigerinio taško (MTT), taip pat 95 proc. atvejų jis turejo ịtakos [2].

Miofascijinis skausmo sindromas yra dažnas, skausmingas griaučių - raumenų sistemos miofascijinių trigerinių taškų sukeltas sutrikimas [13]. MTT kaklo ir pečių raumenyse dažnai vyrauja kartu su kaklo skausmu ir gali prisidèti prie simptomų. Kaklo sritis dažniausiai paveikiama MTT būnant trapeciniame raumenyje, labiausiai - viršutineje jo dalyje [6]. Manoma, jog MTT yra susiję su raumenų veiklos pokyčiais ir turi įtakos kraujo cirkuliacijai ir vietiniam 
metabolizmui [9]. Žinant galimas MTT priežastis svarbu užkirsti kelią jų vystymuisi ir pasikartojimui, taip pat pašalinti esamus MTT [3]. R. M. Bennet teigia, kad aktyvūs MTT dažnai atlieka svarbų vaidmenį sergančiųjų galvos, nugaros, kaklo, žandikaulio, dilbio ir plaštakos skausmams atsirasti, taip pat skausmams dubenyje ir virškinimo trakte [2]. I. Muntianaitè ir kt. pažymi, kad kaklo skausmas gali neigiamai paveikti žmogaus gyvenimo kokybę dèl su juo susijusio mažèjančio darbingumo. Lètinis kaklinès dalies skausmas yra susijęs su funkciniu apribojimu, darbo laiko praradimu, taip pat didina sveikatos sistemos išlaidas ir yra didelè našta gyventojams [16]. Šios problemos yra ypač aktualios išsivysčiusiose pasaulio šalyse, taip pat ir Lietuvoje, todèl labai svarbu skirti kuo daugiau dèmesio kaklo skausmų profilaktikai bei efektyviam gydymui. Yra labai daug panašių lètinio skausmo gydymo būdų, nepriklausomai nuo jo etiologijos ar diagnostikos [8].

Tyrimo tikslas: nustatyti klasikinio masažo ir išeminès kompresijos poveikị kaklo judesių amplitudei ir skausmui.

\section{Metodika}

Tyrime dalyvavo 20 sveikatos sutrikimų neịvardijusių asmenų, kuriems viršutinejje kaklinejje stuburo dalyje nustatytas bent vienas latentinis miofascijinis trigerinis taškas. Tiriamieji atsitiktinès atrankos būdu buvo suskirstyti ị dvi grupes: I grupé, kuriai taikyta išeminè kompresija, II grupei taikytas pečių lanko raumenų klasikinis masažas.

Asmenys ị tyrimą buvo įtraukti remiantis šiais atrankos kriterijais: 1) asmenys, neturintys sveikatos sutrikimų, kurie galètų turèti ịtakos tyrimo rezultatams, 2) savanoriškai sutikę dalyvauti tyrime, 3) bent vienas latentinis miofascijinis trigerinis taškas (LMTT) pečiu lanko raumenyse, 4) amžius nuo 18 iki 30 metų.

I grupę, kuriai buvo taikyta išeminè kompresija, sudare 8 moterys ir 2 vyrai, tiriamujų amžiaus vidurkis $-26,6 \pm 1,17$ metai. II grupę, kuriai taikytas klasikinis kaklo masažas, sudare 8 moterys ir 2 vyrai, kurių amžiaus vidurkis - 27,9 $\pm 0,88$ metai.

LMTT apčiuopos būdu buvo randamas kiekvienam tiriamajam, sutikusiam dalyvauti tyrime. Apčiuopos metu buvo ieškoma ịsitempusio raumens skaidulų dalies ir joje esančio mazgelio, kurị tiriamasis ịvardindavo kaip skausmingą tašką. Palpacija buvo atliekama viršutinejje trapecinio raumens dalyje ir sukamajame galvos raumenyje.

Visiems tiriamiesiems prieš ir po tyrimo buvo vertinama galvos ir kaklo judesių amplitude naudojant goniometrą, taip pat buvo naudojama vizualinè ir skaitmeninè analoginè skausmo skale skausmo intensyvumui nustatyti.

Skausmo intensyvumo vertinimas. Skausmo intensyvumui vertinti buvo naudojama vizualinè ir skaitmeninè analoginè skausmo skalè (VAS, SAS). Skalè sunumeruota nuo 0 iki 10 balų, 0 balų atitinka „nèra skausmo“, o 10 balu - „nepakeliamas skausmas“.

Goniometrija. Kaklo judesių amplitudè buvo vertinama goniometru. Goniometrija - tai judesių amplitudes vertinimas. Tiriamiesiems buvo vertinami visi kaklinès dalies judesiai - kaklo lenkimas, tiesimas, šoninis lenkimas i kairę ir dešinę puses, sukimo amplitudè į kairę ir dešinę puses. Tiriamojo padètis matavimo metu - sèdima.

Išeminė kompresija. Išeminè kompresija taikoma toleruojamo skausmo ribose, pasitelkiant VAS ir SAS. Radus LMTT, buvo taikomas pastovaus intensyvumo spaudimas iki tol, kol tiriamasis įvardydavo skausmo intensyvumo sumažejjimą iki 3 - 5 balų pagal VAS spaudžiamam taške. Išlaikant išeminę kompresiją spaudžiamas raumuo palaipsniui tempiamas iki tol kol skausmas padideja iki $7-8$ balų ir laukiama kol skausmo intensyvumas vèl sumažès iki 3 -5 balų. Išeminè kompresija taikoma viso raumens ilgio ištempimo periodu.

Klasikinis pečių lanko raumenų masažas. Klasikinis masažas atliekamas radus LMTT ir pažymėjus ji X. Masažas atliekamas gulint ant pilvo, tiriamajam atsipalaidavus. Taip pat buvo naudojamas aliejus masažuojamoje vietoje, prieš tai paklausus dèl galimų alerginių reakcijų. Klasikinio masažo metu naudojami keturi būdai - glostymas, trynimas, maigymas ir vibracija.

Matematine statistika. Duomenys buvo apdoroti naudojant Microsoft Excel programą, o duomenų statistinè analizė buvo atlikta naudojant SPSS $₫$ programinę įrangą. Skirtumai laikyti statistiškai reikšmingais, jei $\mathrm{p}<0,05$.

\section{Rezultatai}

Skausmo intensyvumo rezultatai. I ir II grupių asmenų skausmo intensyvumas pradiniame tyrimo taške tarp grupiu statistiškai reikšmingai nesiskyrè.

Tyrimo pradžioje įvertintas kiekvieno tiriamojo LMTT sukelto skausmo intensyvumas. I grupès asmenų skausmo intensyvumas buvo 7,3 $\pm 0,48$ balai, II grupès asmenu $7,2 \pm 0,63$ balai. Po taikytos išeminès kompresijos asmenu skausmo intensyvumas siekè $2,3 \pm 1,15$ balo, o asmenims, kuriems buvo taikomas klasikinis masažas, skausmas sumažejo iki 4,8 $\pm 1,22$ balų. Visų tiriamųjų skausmo intensyvumas reikšmingai sumažèjo $(p<0,05)$. Vertinant skausmo pokyti prieš ir po gydymo, asmenų, kuriems buvo taikoma išeminè kompresija, skausmo pokytis buvo $5,0 \pm 0,0$ balai, o asmenims, kuriems buvo taikomas klasikinis masažas $-2,4 \pm$ 0,52 balai. I grupès asmenų, kuriems buvo taikoma išeminè kompresija, skausmo pokytis buvo reikšmingai didesnis (p $<0,05$ ), nei II grupès asmenų, kuriems buvo taikomas klasikinis masažas (1 pav.). 
Galvos ir kaklo judesių amplitudžių rezultatai. I ir II grupių asmenų galvos ir kaklo judesių amplitudès pradiniame tyrimo taške tarp grupių statistiškai reikšmingai nesiskyrè.

Tyrimo pradžioje I grupès asmenų, kuriems buvo taikoma išemine kompresija, galvos ir kaklo lenkimo judesio amplitudè buvo 39,32 \pm 8,8 laipsniai, o II grupès asmenų, kuriems buvo taikomas klasikinis masažas, galvos ir kaklo lenkimas $-40,33 \pm 7,75$ laipsniai. Po tyrimo I grupès asmenų galvos ir kaklo lenkimo amplitudè padidèjo iki 42,99 $\pm 8,82$ laipsnių, II grupès asmenų - 43,19 \pm 9,17 laipsnių.

Prieš tyrimą I grupès asmenų, kuriems buvo taikoma išeminè kompresija, galvos ir kaklo tiesimo amplitude buvo $38,99 \pm 10,32$ laipsniai, o po tyrimo padidejo iki 45,86 \pm 11,38 laipsnių. II grupès asmenų, kuriems buvo taikomas klasikinis masažas, galvos ir kaklo tiesimo amplitude prieš tyrimą buvo $36,09 \pm 5,58$ laipsniai, po tyrimo $-39,93 \pm$ 8,19 laipsniai.

Prieš tyrimą I grupès asmenų, kuriems buvo taikoma išeminè kompresija, galvos ir kaklo šoninio lenkimo ị kairę judesio amplitudè buvo 27,86 \pm 4,91 laipsniai, o po tyrimo $-32,33 \pm 7,35$ laipsniai. Galvos ir kaklo šoninio lenkimo i dešinę judesio amplitudè prieš tyrimą buvo $28,13 \pm 4,97$ laipsniai, po tyrimo $-30,53 \pm 4,98$ laipsniai.

II grupès asmenų, kuriems buvo taikomas klasikinis masažas, galvos ir kaklo šoninis lenkimas ị kairę prieš tyrimą buvo 26,13 $\pm 3,59$ laipsnių, po tyrimo $-29,06 \pm 5,08$ laipsniai. Galvos ir kaklo šoninis lenkimas ị dešinę prieš tyrimą buvo $26,09 \pm 3,24$ laipsniai, po tyrimo $-29,26 \pm$ 1,89 laipsniai.

Prieš tyrimą I grupès asmenų, kuriems buvo taikoma išeminė kompresija, galvos ir kaklo sukimo ị dešinę judesių amplitudè buvo 61,33 \pm 6,10 laipsniai, po tyrimo padidejjo iki $63,33 \pm 6,45$ laipsnių. Galvos ir kaklo sukimo ị kairę judesių amplitudè prieš tyrimą buvo $60,26 \pm 6,88$, po tyrimo $-60,59$ $\pm 7,22$ laipsniai.

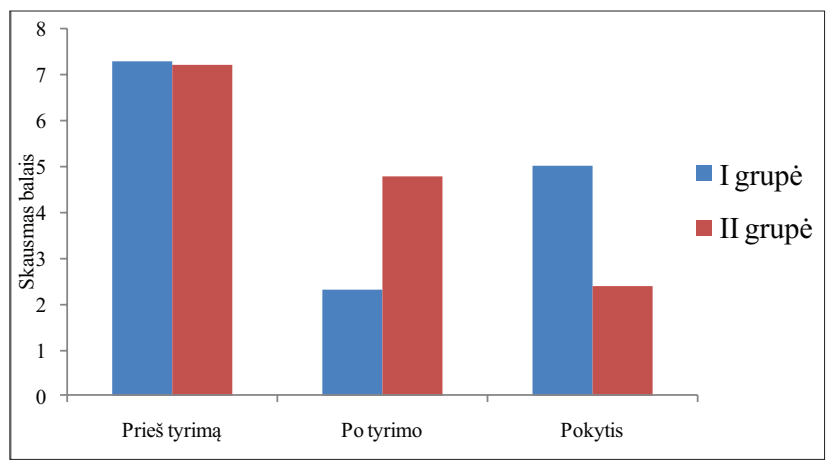

1 pav. I - osios ir II - osios grupių asmenų skausmo intensyvumo kaita.

$*_{p}<0,05$ lyginant skirstinius
Prieš tyrimą, II grupès asmenų, kuriems buvo taikomas klasikinis masažas, galvos ir kaklo sukimo į dešinę judesių amplitudè buvo $62,79 \pm 4,77$ laipsniai, po tyrimo padidèjo iki 64,22 $\pm 6,35$ laipsnių. Galvos ir kaklo sukimo ị kairę judesių amplitude prieš tyrimą buvo 60,86 \pm 5,60 laipsniai, po tyrimo $-63,26 \pm 6,35$ laipsniai.

Visų tiriamujų galvos ir kaklo judesių amplitudžių skirtumai grupių viduje ir tarp grupių statistiškai reikšmingai nesiskyrè $(\mathrm{p}>0,05)$.

\section{Aptarimas}

Latentiniai miofascijiniai trigeriniai taškai dažniausiai siejami su tam tikros kūno dalies judesių amplitudès sumažèjimu ir skausmu judesių metu [18].

Literatūros šaltiniai nurodo daugelį metodų, turinčių ịtakos simptomų, sukeliamų LMTT, mažinimui ir šalinimui. D. Celik ir kt. teigia, kad ittempimo ir atpalaidavimo technika mažina skausmą ir gerina minkštujų audinių funkciją asmenims, kenčiantiems nuo vietinių raumenų skausmų [7]. A. Atienza-Meseguer ir kt. atliktame tyrime nustate, kad aktyvus raumenų tempimo metodas mažina mechaninio skausmo jautrumą trigeriniuose taškuose viršutiniame trapeciniame raumenyje [1]. A. R. Domingo ir kt. teigia, kad masažas mažina skausmą ir didina susitraukiančių struktūrų atpalaidavimą [9]. A. D. Kumbhare ir kt. atlikę tyrimą nustaté, kad botulino toksino injekcijos ị raumenyje esančius MTT ilgesniam laikui sumažina skausmus [13]. S. Koppenhaver ir kt. autorių atliktame tyrime paaiškejjo akupunktūros efektyvumas sąnarių judesių amplitudei [12]. M. Jafari ir kt. teigia, kad utragarsas gerina minkštujų audinių elastingumą [11].

Mūsų atliktame tyrime lyginome dvi minkštųjų audinių mobilizacines technikas, galinčias turèti įtakos LMTT sukeliamiems simptomams - skausmui ir judesių amplitudès sumažejjimui. Tyrimo rezultatai parodè, kad abi poveikio metodikos mažina skausmą minkštuosiuose audiniuose. Tiek klasikinio masažo, tiek išeminès kompresijos grupès asmenims reikšmingai sumažèjo skausmo intensyvumas. Nors abejose grupèse po taikyto gydymo skausmo intensyvumas neviršijo vidutinio skausmo ribų ( 5 balų), tačiau asmenims, kuriems buvo taikoma išeminė kompresija, skausmas sumažèjo labiau nei klasikinio masažo grupèje. Gautus rezultatus galime paaiškinti tuo, kad išeminè kompresija yra gilesnis minkštujų audinių mobilizavimo būdas nei masažas bei kompresija lemia raumens skaidulų ir fascijos plastines minkštujų audinių deformacijas [17, 11]. F. J. MontanezAguilera ir kt. bei B. Cagnie ir kt. atlikę tyrimus teigia, kad išeminè kompresija padidina elektrinį aktyvumą raumenyse, raumenų jègą, padidina skausmo slenkstį LMTT, sumažina MTT jautrumą, nepriklausomai, ar terapija taikoma viena, ar su kitomis metodikomis $[5,15]$. A. R. Domingo ir kt. at- 


\section{4}

likę tyrimą teigia, kad masažas sumažina raumenų įtampą ir skausmą [10]. B. Cagnie ir kt. bei D. Celik ir kt. teigia, kad išemine kompresija didina judesių aktyvią ir pasyvią amplitudes $[4,7]$. Mūsų tyrimo rezultatai nerodo, kad masažas ar išeminès kompresijos metodas padidina kaklinès dalies judesių amplitudes. Gautus rezultatus galime paaiškinti tuo, kad mūsų mažas tiriamujų skaičius neatspindi kitų autorių gautų rezultatų.

Apibendrinant galime teigti, kad minkštujų audinių mobilizacinès technikos mažina simptomus, kuriuos sukelia latentiniai miofascijiniai trigeriniai taškai. Asmenims, jaučiantiems minkštụjų audinių skausmą, galima rekomenduoti savimasažą bei išeminę kompresiją atlikti namų sąlygomis naudojant lauko teniso kamuoliukus ar specialias priemones, skirtas taikyti išeminei kompresijai.

\section{Išvados}

1. Išeminè kompresija sumažina skausmo intensyvumą, sukeliamą lètinių miofascijinių trigerinių taškų, tačiau nedaro įtakos galvos ir kaklo judesių amplitudès kaitai.

2. Klasikinis masažas sumažina lètinių miofascijinių trigerinių taškų sukeliamą skausmo intensyvumą, tačiau nedaro įtakos galvos ir kaklo judesių amplitudès kaitai.

3. Išeminè kompresija veiksmingiau mažina lètinių miofascijinių trigerinių taškų sukeltą skausmą nei klasikinis masažas.

\section{Literatūra}

1. Atienza Meseguer A, Fernández-de-las-Pe-as C, Navarro-Poza JL, Rodríguez-Blanco C, Boscá Gandia JJ. Immediate effects of the strain/counterstrain technique in local pain evoked by tender points in the upper trapezius muscle. Clinical Chiropractic 2006; 9(3):112-118.

https://doi.org/10.1016/j.clch.2006.06.003

2. Benet RM. Myofascial pain syndromes and their evaluation. Article in Bailli \& egraveres Best Practice and Research in Clinical Rheumatology 2007; 21(3):427-45.

https://doi.org/10.1016/j.berh.2007.02.014

3. Bron C, Dommerholt JD. Etiology of myofascial trigger points. Current Pain and Headache Reports 2012; 16(5): 439-444. https://doi.org/10.1007/s11916-012-0289-4

4. Cagnie B, Castelein B, Pollie F, Steelant L, Verhoeyen H, Cools A. Evidence for the use of ischemic compression and dry needling in the management of trigger points of the upper trapezius in patients with neck pain: a systematic review. Am J Phys Med Rehabil 2015;94(7):573-583. https://doi.org/10.1097/PHM.0000000000000266

5. Cagnie B, Dewitte V, Coppieters I, Van Oosterwijck J, Cools A, Danneels L. Effect of ischemic compression on trigger points in the neck and shoulder muscles in office workers: a cohort study. J Manipulative Physiol Ther 2013;36(8):482-489. https://doi.org/10.1016/j.jmpt.2013.07.001

6. Campa-Moran I, Rey-Gudin E, Fernández-Carnero J, ParisAlemany A, Gil-Martinez A, Lerma Lara S, Prieto-Baquero A, Alonso-Perez JL, and La Touche R. Comparison of dry needling versus orthopedic manual therapy in patients with myofascial chronic neck pain: a single-blind, randomized pilot study. Pain Research and Treatment 2015:1-15.

https://doi.org/10.1155/2015/327307

7. Celik D, Mutlu EK. Clinical implication of latent myofascial trigger point. Current Pain and Headache Reports 2013;17(8):353-013-0353-8.

8. Colvin LA, Fallon M. Skausmo ABC. Vilnius, 2012.

9. Dibai-Filho AV, Guirro ECO, Ferreira VTK, Brandino HE, Vaz MOLL, Guirro RRJ. Reliability of different methodologies of infrared image analysis of myofascial trigger points in the upper trapezius muscle. Brazilian Journal of Physical Therapy 2015;19(2):122-128.

https://doi.org/10.1590/bjpt-rbf.2014.0076

10. Domingo AR, Diek M, Goble KM, Maluf KS, Goble DJ, Baweja HS. Short duration therapeutic massage reduces postural upper trapezius muscle activity. Neuroreport 2017;28(2):108110. https://doi.org/10.1097/WNR.0000000000000718

11. Jafari M, Bahrpeyma F, Togha M. Effect of ischemic compression for cervicogenic headache and elastic behavior of active trigger point in the sternocleidomastoid muscle using ultrasound imaging. J Bodyw Mov Ther 2017; 21(4):933-939. https://doi.org/10.1016/j.jbmt.2017.01.001

12. Koppenhaver S, Embry R, Ciccarello J, Waltrip J, Pike R, Walker M, Fernández-de-Las-Pe-as C, Croy T, Flynn T. Effects of dry needling to the symptomatic versus control shoulder in patients with unilateral subacromial pain syndrome. Manual Therapy 2016; 26:62-69.

https://doi.org/10.1016/j.math.2016.07.009

13. Kumbhare DA, Elzibak AH, Noseworthy MD. Assessment of myofascial trigger points using ultrasound. American Journal of Physical Medicine \& Rehabilitation 2016; 95(1):72-80. https://doi.org/10.1097/PHM.0000000000000376

14. $2014 \mathrm{~m}$. Lietuvos gyventojų sveikatos statistinio tyrimo rezultatai. Lietuvos statistikos departamentas, 2015:11-16.

15. Montanez-Aguilera FJ, Valtuena-Gimeno N, Pecos-Martin D, Arnau-Masanet R, Barrios-Pitarque C, Bosch-Morell F. Changes in a patient with neck pain after application of ischemic compression as a trigger point therapy. Journal of Back and Musculoskeletal Rehabilitation 2010;23:101-104.

https://doi.org/10.3233/BMR-2010-0255

16. Muntianaitė I., Juocevičius A., Varnienė L., Matulevič R. Skirtingų kineziterapijos metodų efektyvumas kaklinès dalies skausmą patiriantiems biuro darbuotojams. Gerontologija, 2014; 15(3):177-183.

17. Nguyen B. Myofascial trigger point: symptoms, diagnosis, intervention, musculoskeletal disorder 2012. 
18. Simons DG. Understanding effective treatments of myofascial trigger points. J Bodyw Mov Ther 2002;6:81-8.

https://doi.org/10.1054/jbmt.2002.0271

\section{EFFECT OF THE CLASSICAL MASSAGE AND} ISCHEMIC COMPRESSION ON THE AMPLITUDE OF NECK MOVEMENT AND PAIN

P.Zachovajevas, E.Kačinskaitė, B.Zachovajevienė, V.Kaktienè

Key words: neck pain, classical massage, ischemic compression, range of motion.

Summary

Neck pain is one of the most common pains. The prevalence of neck pain in the population is between $10 \%$ and $15 \%$, more prevalent among women than men [6]. Myofascial pain syndrome is a common, painful disorder of musculo-skeletal system caused by myofascial triger points [13].

Methods. The study involved 20 subjects with at least one latent myofascial trigger point in the upper cervical spine and with no other health disorders that could affect the outcome of the study. Two groups were formed. Ischemic compression procedure was applied to the subjects of the I group $(n=10)$, group II patients ( $n$ $=10$ ) were subjected to classical massage on the side where the latent myofascial trigger point was detected. Before and immediately after the study, the amplitude of neck movements was asses- sed using a goniometer, a visual and digital analogue pain scale was also used to determine the intensity of pain.

Results. At the beginning of the study, each subject's intensity of pain induced by LMTT was evaluated. In group I the intensity of pain was 7,3 $\pm 0,48$ points, in group II it was 7,2 $\pm 0,63$ points. After ischemic compression was applied, the intensity of pain reduced to $2.3 \pm 1.15$ points, and for those undergoing classical massage, the pain reduced to $4.8 \pm 1.22$ points. The pain intensity of all subjects significantly decreased $(\mathrm{p}<0.05)$. When assessing the change in pain before and after treatment, we determined that the change in pain in group I, which had ischemic compression applied, was significantly higher $(\mathrm{p}<0.05)$ than in group II patients undergoing classical massage.

Conclusions. 1. Ischemic compression reduces the intensity of pain caused by chronic myofascial trigger points, however it does not affect the change in the amplitude of the head and neck movements. 2. Classic massage reduces the intensity of pain caused by chronic myofascial trigger points, but does not affect the change in the amplitude of head and neck movements. 3. Ischemic compression reduces the pain caused by chronic myofascial trigger points more effectively than classical massage.

Correspondence to: viktorija.repsaite@go.kauko.lt

Gauta 2018-10-11 